\title{
Grupy wsparcia, samopomocy i stowarzyszenia rodziców dzieci z zaburzeniami ze spektrum autyzmu - narzędzie wsparcia emocjonalnego, informacyjnego czy instrumentalnego?
}

\author{
Support groups, self-help groups and associations of parents of children with autism - \\ the source of emotional, informational or instrumental support?
}

\author{
Ewa Dobrogowska-Schlebusch $\bowtie$
}

Uniwersytet Jagielloński, Collegium Medicum, Zakład Informacji Naukowej, ul. Grzegórzecka 20, 31-531 Kraków Jagiellonian University in Kraków, Department of Information Science

$\triangle$ ewa.dobrogowska@gmail.com

\begin{abstract}
Introduction: Getting a diagnosis of autism spectrum disorder and the problems related to raising a child with a disability can be a major source of stress for parents of children with autism. Parents often join parent support groups to better deal with this situation and be able to share their experiences with other people. The aim of the study was to assess the importance of joining such groups for parents and to identify types of social support offered through such groups.

Materials and methods: The study was part of a larger research project. Twelve in-depth interviews were conducted with parents of children with autism from Małopolskie Province, Poland. Seven of them had some experience with membership of various support groups for parents. Transcripts of interviews were analyzed using interpretative phenomenological analysis.
\end{abstract}

Results: Seven themes were identified in which parents talked about their feelings connected with participation in support groups for patients with autism.

Conclusions: Being a member of support groups, self-help groups or associations of parents of children with autism could be an important source of: emotional support (giving parents the sense of security and belonging to the group), and informational and instrumental support (thanks to information and instructions received from other parents). Parents were not only the passive recipients of support, but active individuals who were providing emotional and informational support for other parents. Seeing others as a reference point, parents could more easily adapt to the situation of raising a child with special needs and achieve the phase of constructive adaptation.

Keywords: social support; psychosocial support systems; autistic disorder; parents; qualitative research.

\begin{abstract}
ABSTRAKT
Wstęp: Stwierdzenie zaburzeń ze spektrum autyzmu (ASD) u dziecka i problemy związane z wychowywaniem dziecka niepełnosprawnego mogą być dla rodziców istotnym źródłem stresu. Aby łatwiej poradzić sobie z sytuacją niepełnosprawności dziecka i mieć możliwość dzielenia się z innymi rodzicami swoimi doświadczeniami i przeżyciami, rodzice dołączają do grup wsparcia dla rodzin.

Celem badania było sprawdzenie, jakie znaczenie dla rodziców dzieci z ASD mają organizowane przez nich grupy wsparcia, samopomocy i stowarzyszenia oraz jakiej formy wsparcia są one źródłem.

Materiały i metody: Badanie było częścią większego projektu badawczego. W jego ramach przeprowadzonych zostało 12 wywiadów pogłębionych z rodzicami dzieci z ASD z województwa małopolskiego. Doświadczenia związane z przynależnością do różnego typu grup miało 7 z przebadanych rodziców. Transkrypty wywiadów analizowano w odwołaniu do założeń analizy fenomenologicznej.
\end{abstract}

Wyniki: Wyodrębniono 7 wątków tematycznych, w których rodzice mówili o swoich odczuciach związanych z uczestnictwem w grupach wsparcia.

Wnioski: Uczestnictwo w grupach wsparcia, samopomocy czy stowarzyszeniach jest przede wszystkim dla rodziców źródłem: wsparcia emocjonalnego (dając im poczucie bezpieczeństwa i przynależności do grupy), wsparcia informacyjnego i instrumentalnego (dzięki radom, ale też instruktarzowi otrzymywanemu od innych rodziców), a także wsparcia opiekuńczego (wsparcie polegające na zastępowaniu rodziców w sprawowaniu opieki nad dzieckiem). Rodzice byli nie tylko biernymi odbiorcami wsparcia, lecz także jego dawcami, udzielając wsparcia o charakterze informacyjnym, instrumentalnym i emocjonalnym innym rodzicom. Widząc innych jako punkt odniesienia, rodzice mogli też łatwiej godzić się z faktem wychowywania dziecka niepełnosprawnego, czyli osiągać fazę konstruktywnego przystosowania się.

Słowa kluczowe: wsparcie społeczne; psychospołeczne systemy wsparcia; zaburzenie autystyczne; rodzice; badanie jakościowe. 


\section{WSTĘP}

Stwierdzenie zaburzeń ze spektrum autyzmu (ASD) u dziecka i problemy związane z wychowywaniem dziecka niepełnosprawnego mogą być dla rodziców istotnym źródłem stresu [1]. Po otrzymaniu diagnozy mogą oni przechodzić przez fazy kryzysu zbliżone do modelu 5 stadiów żałoby wg Elisabeth Kübler-Ross. Są to fazy: szoku, kryzysu emocjonalnego, pozornego przystosowania się oraz konstruktywnego przystosowania się [2]. Osiągnięcie ostatniej fazy adaptacji - konstruktywnego przystosowania się zależy w dużej mierze od posiadanych przez rodzinę zasobów, a także otrzymywanego wsparcia społecznego [3].

Aby lepiej poradzić sobie z faktem niepełnosprawności dziecka i mieć możliwość dzielenia się swoimi doświadczeniami z innymi ludźmi znajdującymi w podobnej sytuacji, rodzice często dołączają do grup wsparcia dla rodzin [4]. Zdaniem Law i wsp. takie grupy są prowadzone przez specjalistów lub przez samych rodziców, a ich głównym celem jest oferowanie rodzinie przyjaźni, wsparcia, dostarczanie informacji oraz ułatwianie dzielenia się doświadczeniami z innymi, co zmniejsza stres i poczucie izolacji, a także pomaga łatwiej przystosowywać się do sytuacji posiadania dziecka niepełnosprawnego [4, 5]. W wielu badaniach sprawdzane było, jakie korzyści rodzice dzieci niepełnosprawnych przypisują uczestnictwu w grupach wsparcia dla rodzin (co można znaleźć w przeglądzie systematycznym Shillinga i wsp. [6]), jednak jak do tej pory brakuje badań o charakterze jakościowym, których przedmiotem są doświadczenia rodziców dzieci z ASD związane $\mathrm{z}$ uczestnictwem w tego typu grupach.

Celem badania było sprawdzenie, jakie znaczenie dla rodziców dzieci z ASD mają organizowane przez nich grupy wsparcia, samopomocy i stowarzyszenia oraz jakiej formy wsparcia społecznego (emocjonalnego, informacyjnego, instrumentalnego) są one źródłem.

Badanie było częścią większego projektu badawczego, który stawiał sobie za cel sprawdzenie, w jaki sposób rodzice dzieci z ASD interpretują i postrzegają problemy napotykane w trakcie diagnozowania dziecka i po otrzymaniu diagnozy (ze szczególnym uwzględnieniem problemów w dostępie do informacji) oraz jakie działania podejmują, żeby te problemy przezwyciężyć.

\section{MATERIAtY I METODY}

Ponieważ skupiono się na opisie doświadczania problemów napotykanych przez rodziców w trakcie diagnozowania dziecka i po otrzymaniu diagnozy, zdecydowano się na jakościowy charakter badania. Podejściem filozoficznym, do którego się odwołano, było podejście fenomenologiczne w ujęciu interpretatywnym. Fenomenologia stawia sobie za cel zrozumienie badanego zjawiska takim, jakim go doświadczają osoby badane, i maksymalnie bliskie prawdy opisanie go, bez przyjmowania apriorycznych założeń [7].

W okresie od czerwca 2016 r. do maja 2017 r. przeprowadzono 12 wywiadów pogłębionych z rodzicami dzieci z ASD. Położono nacisk na to, by dać osobom badanym jak największą swobodę wypowiedzi. Wywiady trwały od 50 min do blisko 4 godz. Rodzice byli rekrutowani za pośrednictwem działających na terenie Województwa Małopolskiego przedszkoli, szkół i poradni specjalizujących się w terapii dzieci z ASD oraz stowarzyszeń zrzeszających rodziców, a także poprzez prywatne kontakty autorki badania. W większości w badaniu uczestniczyły kobiety (11 osób). Dwie osoby były ze sobą spokrewnione (małżeństwo), ale udzieliły wywiadu niezależnie od siebie. W większości osoby badane były matkami chłopców (10 osób), 1 matka miała dwójkę dzieci z ASD (dziewczynka z diagnozą autyzmu i chłopiec z zespołem Aspergera), 1 osoba dziewczynkę. Wiek dzieci wahał się 4-16 lat. Większość dzieci miała postawioną diagnozę autyzmu (lub autyzmu atypowego), 4 dzieci miało diagnozę zespołu Aspergera, a w 1 przypadku diagnoza była niespecyficzna. Większość rodziców zamieszkiwała na terenie Krakowa i sąsiednich gmin, 1 matka pochodziła z Nowego Sącza; 7 matek i ojciec byli czynni zawodowo, 4 matki nie pracowały. Więcej danych demograficznych rodziców (wiek) nie było zbieranych. Pięciu rodziców uczestniczących w badaniu było członkami 3 różnych form organizacji zrzeszających rodziców dzieci z ASD: stowarzyszeń, grupy wsparcia prowadzonej przez specjalistów oraz grupy samopomocowej stworzonej z inicjatywy samych rodziców. Małżeństwo w momencie trwania badania nie należało do żadnej grupy wsparcia, ale korzystało z opieki wytchnieniowej organizowanej przez Krajowe Towarzystwo Autyzmu na terenie Krakowa. W niniejszej pracy skupiono się na analizie tego, jakie znaczenie rodzice dzieci z ASD przypisują uczestnictwu w tego typu zrzeszeniach.

Na przeprowadzenie badania została udzielona zgoda Komisji Bioetycznej Uniwersytetu Jagiellońskiego. Przed rozpoczęciem wywiadu rodzice byli informowani o celu badania i wszelkich niedogodnościach mogących wyniknąć z udziału w badaniu. Wszystkie wywiady były rejestrowane na dyktafon, po czym dokonywano ich transkrypcji. Z transkrypcji usuwane były wszelkie dane, które mogłyby pozwolić na identyfikację poszczególnych osób badanych i ich dzieci. Analizy wywiadów dokonano w odwołaniu do założeń analizy fenomenologicznej, zgodnie z metodą analizy tekstu zaproponowaną przez Hycnera [8]. Obejmowała ona następujące etapy: najpierw kilkakrotnie przeczytano tekst wywiadu w celu uzyskania sensu całości. W kolejnym etapie zrekonstruowano ogólne jednostki znaczeniowe, dokonując krystalizacji i kondensacji tego, co powiedział dany uczestnik badania. Następnie z jednostek znaczeniowych wybrano te, które odnosiły się do wybranego tematu badawczego. W kolejnym etapie wyodrębnione jednostki znaczeniowe zostały powiązane w wiązki znaczeniowe (odnoszące się do tematu badawczego), które następnie uporządkowano w bardziej centralne tematy. Następnie pisano podsumowanie każdego wywiadu. W ostatnim etapie analizy dokonano podsumowania wszystkich wywiadów, szukając cech wspólnych w sposobie interpretowania przez rodziców doświadczanych problemów, ale wyróżnione zostały również tematy unikalne, wskazane przez pojedynczych uczestników badania. Wykorzystano tutaj adaptację metody analizy tekstu Hycnera zaproponowaną przez Koneckiego [7]. 
Dane zebrane poprzez wywiady pogłębione z rodzicami dzieci z ASD uzupełnione zostały o dane zebrane w trakcie obserwacji uczestniczącej pełnej. Autorka badania, sama będąca rodzicem dziecka z ASD, w okresie od listopada 2016 r. do maja 2017 r. uczestniczyła w spotkaniach grupy wsparcia dla rodziców organizowanej przez jedną z krakowskich poradni pedagogiczno-psychologicznych (była to grupa o charakterze otwartym i nieterapeutycznym). Obserwacja miała charakter jawny. Dane z obserwacji pełnej uczestniczącej w tej publikacji wykorzystane zostały jedynie do pogłębienia interpretacji znaczenia, jakie rodzice przypisują uczestnictwu w zrzeszeniach skupiających rodziców, a szczegółowe wyniki tej części badania będą raportowane w kolejnych publikacjach.

\section{WYNIKI}

W wyniku analizy fenomenologicznej transkryptów wywiadów w ich części dotyczącej doświadczeń rodziców związanych z uczestnictwem w grupach wsparcia, grupach samopomocowych i stowarzyszeniach rodziców wyłoniono 7 następujących tematów:

1. Bo każdy tam swoja ścieżkę przeszedt, coś tam usłyszał.

2. Bo wszędzie gdzie indziej to mówi to jest traktowany jako taki trochę... coś dziwnego, natomiast tam trafiamy na grupe ludzi, którzy mają podobne problemy, podobne zachowania dzieci.

3. Bo nam tego nikt nie tłumaczył. Więc, żeby było komuś łatwiej.

4. No i właśnie to sobie uświadomiłam, że może być tak, że nie damy rady dalej iść.

5. Ja, cały ten mój proces to tak odbieram jak takie błądzenie po omacku... natomiast oni idq kierunkowo, oni wiedza, czego szukaja.

6. Także nowi ludzie, coś nowego, świeżego przynosza, no i toczymy to, że tak powiem.

7. To jedna z nielicznych organizacji, która jako jedyna tak naprawdę chyba, takie coś więcej z siebie daje.

Jako tytuły tematów wykorzystane zostały fragmenty wypowiedzi rodziców, które najbardziej oddają istotę poszczególnych wątków tematycznych.

\section{Bo każdy tam swoją ścieżkę przeszedt, coś tam usłyszat}

Uczestniczenie w grupach zrzeszających rodziny dzieci z ASD jest dla rodziców przede wszystkim źródłem wsparcia informacyjnego. Według określenia jednej z matek uczestniczących w badaniu są one czymś w rodzaju centrum informacyjnego, gdzie rodzice mogą się dzielić swoimi doświadczeniami, bo każdy tam swoją drogę przeszedł, czy coś usłyszał. Jedną z podstawowych funkcji takich grup jest wymiana informacji i porad na temat wszystkiego, co w danej chwili dotyczy rodziców. Każdy wnosi na spotkania jakąś wiedzę, która może się przydać innym i ułatwić załatwienie różnych spraw. Ważne są nie tylko doświadczenia rodziców związane z szukaniem pomocy dla dziecka, lecz także ich wiedza zawodowa, wcześniejsza aktywność w innych organizacjach pożytku publicznego czy po prostu ogólna informacja o tym, co „w trawie piszczy”.
No i to jest, mogę nazwać. To jest centrum informacyjne (matka nr 3).

Natomiast jaka jest podstawowa jakby funkcja tych spotkań? To, że rodzice mówią, udzielają informacji, czyli to wszystko to, co się dzwoni od pana do plebana, to się zadaje pytanie, jak ktoś przeszedł tę drogę, ma gotowe odpowiedzi, to ich udziela. To potrafi skrócić czas oczekiwania, albo nakierować na... (matka nr 3).

Tak. Tak, tak, tak, porównujemy. Staramy się. No bo oprócz tego każdy jakąś swoją historię opowiada, prawda? No to jeszcze czasami zdarza się, że ktoś sobie z czymś poradził, no to się dzieli tym, prawda? Ktoś uzyskał orzeczenie o niepełnosprawności, prawda, no to po prostu mówi po kolei i jest wymiana obserwacji na temat leków stosowanych, prawda? Niektóre matki znaja się na lekach jak farmaceutki, to jest, dla mnie to był szok (...). Do takich rzeczy można się przygotować na takich spotkaniach, jak się rzuci hasło (matka nr 3).

Tak. My się spotykamy i np. mamy na samym początku wysłuchujemy osób, które pierwszy raz są, one maja pierwszeństwo. Potem wysłuchujemy rodziców, którzy przyszli z jakimś problemem i wszyscy wypowiadamy się, wspieramy, mówimy, co ma zrobić z tym problemem, gdzie się udać itd. Kolejna sprawa, to jest np., mówimy o różnych rzeczach, typu książka. Ostatnio promowałam, to znaczy promowałam, mówiłam, że fajna książka, że przeczytałam takq i się wymieniamy, puszczam książkę w obieg (matka nr 2).

Bo jak na początku się spotykaliśmy, to było na zasadzie, każdy właśnie coś nowego wnióst. Jedni to SUO, inni coś tam. Później A. poszedł jako pierwszy do szkoły, więc wniósł tę szkołę. I się zaczęło, więc tutaj było (matka nr 4).

No to na początku, zawsze, jak spotykaliśmy się $w$ kawiarniach, czy tam gdzieś, bo nie mieliśmy lokum, no żeśmy gdzieś... to każdy coś tam opowiadał swoje doświadczenia z różnymi terapiami, behawioralna, jakąś tam inna, ten tam był tu, tutaj to jest beznadziejne, czy lekarz, czy badanie tam diagnostyczne $w$ kierunku autyzmu, te grzybice, prawda, przewodu pokarmowego, że w Polsce te badania tak naprawdę nie wychodza, mają inne standardy, wysyłaja do Niemiec, a to gdzie, i to taka informacja była. Dużo różnych informacji. Bo każdy tam swoją ścieżkę przeszedt, coś tam usłyszał, albo jakieś suplementacje, albo o diecie dużo było, także... (matka nr 10).

Raz w miesiacu sq spotkania w kawiarni, plus te spotkania grup roboczych, jak jest potrzeba, coś robimy, każdy dostaje jakiś tam zestaw zadań, żeby coś spenetrować, nie wiem, mamy prawnika, to M. nam szuka jakieś prawne aspekty, ktoś tam jakieś inne aspekty... (matka nr 10).

\section{Bo wszędzie gdzie indziej to mówi to jest traktowany jako taki trochę... coś dziwnego, natomiast tam trafiamy na grupę ludzi, którzy mają podobne problemy, podobne zachowania dzieci}

Uczestnictwo w spotkaniach daje poczucie przynależności, identyfikacji z jakąś grupą (gdzie są „sami swoi”), co ma istotne znaczenie szczególnie w przypadku rodziców, którzy dotychczas doznawali poczucia izolacji i osamotnienia. Pojawia się poczucie znalezienia się we właściwym miejscu, w grupie „wzajemnego zrozumienia”, w której nikt nie zarzuci niewłaściwego 
sposobu wychowywania dziecka ani choroby psychicznej (nie jest się jedynym, któremu odbiło), gdy przypisuje się dziecku różne zaburzenia. Przede wszystkim są w grupie, z którą mogą się utożsamiać, bo problemy doświadczane przez rodziców dzieci z zespołem Aspergera czy autyzmem są zazwyczaj podobne (kłopoty ze szkołą, z diagnozowaniem, a przede wszystkim zarzuty o złe wychowanie). Przynależność do takiej grupy i możliwość integracji z innymi w podobnej sytuacji życiowej daje rodzicom duże poczucie bezpieczeństwa. Tym, co szczególnie łączy, są wspólne doświadczenia i zbliżone problemy z dzieckiem. Udział w różnych aktywnościach organizowanych przez rodziców jest też dla nich szansą na nawiązanie przyjaźni.

Bo to, że nie jest się jedynym, któremu odbiło, prawda, bo matka, która ma chorobę psychicznq i dopisuje dziecku różne zaburzenia, no bo ja odczuwałam takie traktowanie, prawda? A tam się okazuje, że jest takich więcej i każdy ma problem z diagnozowaniem. Większość ma problem ze szkoła, te problemy ze szkoła sq też dość podobne (matka nr 3).

A jest to grupa, w której nikt nikomu nie powie, że jego dziecko jest źle wychowane. Więc daje to poczucie ogromnego bezpieczeństwa, prawda? Bo sa już ludzie, którzy nigdzie w Krakowie nie pójdq ze swoim dzieckiem, bo się po prostu boją. Tak? A tam się pójdzie. Poza tym jest to grupa jakby wzajemnego zrozumienia. A ja miałam tam sytuację taka, że dzieci, które czekały na swojq kolej przy warsztatach, zaczęły rysować po tablicy, więc mój syn musiał oczywiście opuścić salę, i gdyby nie reakcja matek, które odsunęły dzieci od tej tablicy, nie miałby możliwości wypróbowania robienia tam czegoś, kiedy przyszła jego kolej (...). I tutaj reakcja matek była taka, której nie da się... nigdy więcej w życiu nie spotkałam tak szybkiej reakcji i takiego zrozumienia. Bo mimo tego, że akurat nie spotkałam się nigdzie z takimi akurat nadwrażliwościami, jakie ma mój syn, ale jakby rozumiana jest grupa tych problemów, prawda, i reakcja jest taka odpowiednia. I tam... (matka nr 3).

Co jest charakterystyczne dla tych ścieżek, to zarzuty o złe wychowanie. To się prawie każdemu zdarzyło, prawda, dlatego że przy autyzmie to sq... łatwej jest zobaczyć od razu zaburzenie, tak. Natomiast przy zespole Aspergera, jeszcze jak nie ma jakiś nietypowych ruchów (...). To jest wspólne dla rodziców: PROBLEMY z diagnozowaniem sq wspólne dla większość rodziców. Zawsze jest pytanie, jest też pytanie dla osób, które mają podejrzenie, że ich dzieci maja zespół Aspergera, gdzie mają pójść. No to jest, nie wiadomo, co doradzać, dlatego, że jest bardzo ciężko po prostu. Jest ciężko właśnie z diagnozowaniem właśnie zespołu Aspergera. Częsta jest też taka sytuacja, i to jest właśnie takie dla rodziców, takie odczucie, że trafiłem do właściwej grupy. Przychodzi ktoś nowy i mówi: moje dziecko się zachowuje tak i tak, i wtedy dwie trzecie rodziców kiwa głowami, że jego dziecko też. I wtedy, prawda, ten rodzic ma takie zdziwienie. Bo wszędzie gdzie indziej to mówi to jest traktowany jako taki trochę... coś dziwnego, natomiast tam trafiamy na grupę ludzi, którzy maja podobne problemy, podobne zachowania dzieci (matka nr 3).

I właśnie to jest coś takiego, że tak właśnie jeździmy tutaj, do M., gdzie się możemy pośmiać, jeden drugiemu coś powie, i łatwiej nam się zrozumieć, bo my wszyscy mamy takie dzieci.
Bo ja też mam przyjaciółkę ze zdrowym dzieckiem, która (...) zna A. od urodzenia, no, ale ona nie rozumie, bo ona ma zdrowe dziecko. No... N. rozumie A. i jest wszystko OK, bo go zna od zawsze. Ale nagle, gdyby go musiała poznać, ktoś kto poznaje, to sa dziwne te dzieci, one sq dziwne, dziwaki, no nie oszukujmy się, no... (matka nr 4).

Dla rodziców ważny jest moment przyłączenia się do grupy. Można powiedzieć, że stanowi on swojego rodzaju rytuał przejścia, od którego coś ważnego zaczyna dziać się w ich życiu. Sami rodzice nie stwierdzają dokładnie, dlaczego uważają ten moment za przełomowy, ale na podstawie ich wypowiedzi można wywnioskować, że dzięki aktywności, w którą są zaangażowani, uczestnicząc w jakimś stowarzyszeniu, grupie wsparcia czy samopomocowej, mają większe poczucie samoefektywności czy kontroli nad sytuacją.

Jeżeli chodzi natomiast o motywacje przystąpienia do tego typu grup, to są one zróżnicowane. Z jednej strony może to być potrzeba pogłębienia wiedzy na temat ASD, ze względu na jakieś niezałatwione do końca sprawy czy bycie dopiero $\mathrm{w}$ początkowej fazie przystosowania po otrzymaniu diagnozy (przed nami jeszcze daleka droga). Często rodzice sami podejmują decyzję utworzenia grupy samopomocowej czy stowarzyszenia, ze względu na konieczność podjęcia jakichś działań dla dobra dzieci (np. pomoc poradni specjalizującej się w terapii autyzmu w staraniach o nowy grant) lub zrobienia czegoś dla dobra innych rodziców.

I później myśmy właśnie, tam poznałam trochę tych rodziców na Z. i utworzyliśmy to Stowarzyszenie. I tak się zaczęło... także byłam w tej grupie, która tworzyła, że tak powiem, to Stowarzyszenie. Wystarczyło być $w 15$ osób, bo tam ta poradnia miała trochę kłopotów, no i spotkanie tam było z dyrektorem poradni, żeby jednak rodzice też jakiś tam głos dali, no i do ministerstwa, do ministerstwa zdrowia, że nie mają dotacji już, (...) więc myśmy takie działania podjęli, że zawiq̨zaliśmy właśnie to stowarzyszenie. I tak się zaczęło (matka nr 11).

Natomiast jak ja już byłam po diagnozie, to wygooglowałam w nocy o północy we wrześniu, jak P. trafił do nowej szkoły, a ja stwierdziłam, no dobra on jest $w$ nowej szkole, a teraz co ja. Tak, bo szkołę dla rodziców miałam wcześniej, parę ksiqżek przeczytałam, te, które znałam, no, ale miałam tę świadomość, że przed nami jest jeszcze bardzo daleka droga, tym bardziej, że wtedy, wtedy było jeszcze bardzo ciężko z zachowaniem P. No i wygooglowałam spotkania dla rodziców, z zespołem Aspergera, które są przy poradni na S. (matka nr 3).

W końcu stwierdziliśmy, że w S. nie ma żadnej takiej grupy, która, może dzieciom by też pomagała, ale rodzicom, prawda, właśnie w celach, gdzie się dalej zwrócić, jak gdzie iść, co zrobić, i ta grupa powstała 2 lata temu z naszej inicjatywy tu (matka nr 4).

\section{Bo nam tego nikt nie tłumaczyt. Więc, żeby było komuś łatwiej}

Duże znaczenie dla rodziców ma również możliwość pomocy innym rodzicom, którzy znajdują się w podobnej co oni sytuacji. Ta chęć niesienia pomocy w dużej mierze może wynikać z faktu, że często oni sami, gdy próbowali zdiagnozować dziecko i później, gdy szukali dla niego odpowiedniej formy 
terapii, byli tej pomocy pozbawieni. Wiedząc, jakie skutki niesie za sobą bycie pozostawionym samemu sobie, bez żadnego wsparcia, i do czego może to doprowadzić, jeżeli chodzi o stan emocjonalny (często doprowadzając do depresji), próbują oni pomóc innym. Często rodzice „weterani” mają poczucie, że to oni są tymi, którzy przecierają szklaki dla rodziców młodszych dzieci.

Między sobq właśnie, jeżeliby ktoś by przyszedł nowy, to wtedy właśnie można podać mój numer telefonu czy kogokolwiek, zawsze znajdujemy na to czas, żeby jakoś tam pomóc, prawda? Mu doradzić. Bo była, nie tak dawno mama z dzieckiem, które dopiero zaczyna diagnozę, więc jest to wtedy już łatwiej. Idź tu, zrób to, takie papiery masz załatwić. Bo nam tego nikt nie tłumaczył. Więc, żeby było komuś łatwiej (matka nr 4).

Tak, jak najbardziej, jak ktoś przyjdzie, jak ktoś przyjdzie, to nikt nikomu pomocy nie odmówi, bo to o to głównie chodziło. Czyli myśmy byli bez tej pomocy. Tam każdy sobie coś robit, kombinował... (matka nr 4).

I jest taki moment, $w$ którym człowiek poszukuje informacji. I tej informacji nie ma i musi być tym pierwszym, który, prawda, to znajdzie, natomiast bardzo często spotyka się z tym, że przy diagnozowaniu, $w$ trakcie diagnozowania, po diagnozie matki mają depresję i to taka, prawdziwie leczona, prawda. I ja może nie miałam aż tak bardzo, ale jak przypomnę sobie swój stan w tym okresie, to po prostu... zaraz mi się chce pomagać innym, żeby uniknęli tego (matka 3).

No, powiedzmy... To znaczy problem polega na tym, że moje dziecko jest duże, prawda. I my jesteśmy, my... przecieramy te szlaki tak naprawdę, prawda? (matka $\mathrm{nr} 3$ ).

\section{No i właśnie to sobie uświadomiłam, że może być tak, że nie damy rady dalej iść}

Uczestnictwo w grupach zrzeszających rodziców dzieci z ASD może też ułatwiać akceptację niepełnosprawności dziecka i różnych wynikających z tego ograniczeń, np. faktu, że być może nigdy nie będzie ono w stanie ukończyć szkoły, a także w pewnym sensie pozwala im wyobrazić sobie, czego mogą się spodziewać w przyszłości (obserwując matki dorastających lub dorosłych dzieci). Pomaga również lepiej poznać istotę zaburzenia, odróżnić, które cechy są efektem zaburzenia, a które złego wychowania bądź lenistwa dziecka. Dzięki temu rodzice nabywają większej wiedzy i zaufania do siebie dotyczącego sposobu postępowania z dzieckiem. To doświadczenia innych rodziców legitymizują w pewnym sensie tę wiedzę.

Ale ogólnie rzeczywiście ja słucham np. innych tych mam, to sobie dużo rzeczy też uświadamiam, jak to będzie, jak będzie trochę starszy. Że w sumie, jak usłyszałam takie zdanie tej jednej z mam, że dziecko no w sumie wybrało szkołę taka, że nie ma kredy, bo nie znosi kredy, tylko wystarczy, że sq pisaki, to ważne, że chodzi i chce mu się chodzić, to jest już dużo. Że np. może nie zdawać egzaminów i trzeba będzie się z tym pogodzić. Że po prostu będa np. z ortografią problemy, czy z matematyka (...). I dużo sobie takich rzeczy uświadomiłam, nad którymi bez mała płakałam (...). Ale mówię, jak on nie zda podstawowego, nie wiem, matury czy z podstawówki do gimnazjum, z gimnazjum do średniej, no to ja mówię: no to jak my ruszymy?! (...). No i właśnie to sobie uświadomiłam, że może być tak, że nie damy rady dalej iść (matka nr 5).

Dla mnie też ma znaczenie, bo ja np. się zastanawiam, czy dana cecha mojego syna to jest tylko lenistwo np., czy to wynika jakoś z zespołu. Bo ja wtedy staram się reagować inaczej, albo silniej go dociskam, albo słabiej go dociskam. I np. rzucam hasło na forum: kto ma taki a taki problem, albo kto ma takq a takq obserwację. I tutaj po prostu patrzy się procentowo. I ja zadaję pytania o rzeczy, których nie ma w opracowaniach. Albo - może ja się nie spotkałam po prostu. Może jeszcze nikt się na tym nie zastanawiał, prawda? Ale jeżeli, nie wiem, 60 czy 70\% rodziców potakuje, prawda, no to ja się muszę na tym zastanowić, że może to wynika z zespołu, tylko jakby nikt tego... (matka nr 3).

\section{Ja, cały ten mój proces to tak odbieram jak takie błądzenie po omacku... natomiast oni idą kierunkowo, oni wiedza, czego szukaja}

Rodzice widzą w osobach uczestniczących w zrzeszeniach skupiających rodziców punkt odniesienia i porównania. Czasami to odniesienie może przybierać formę porównania społecznego w dół lub w górę. Zwłaszcza poprzez obserwację rodziców starszych dzieci, którzy w trakcie drogi do diagnozy dziecka napotykali na liczne trudności i poprzez niewiedzę, co dolega dziecku, popełniali błędy wychowawcze, rodzice nabierają przeświadczenia, że być może ich dziecka wcale nie spotkał najgorszy los. Z kolei rodzice starszych dzieci zauważają różnice między drogą, którą oni przebyli, diagnozując dziecko, a rodzicami młodszych dzieci, którzy nie błądzą już po omacku, ale idq bardziej kierunkowo i wiedzą, czego szukają. Dzięki porównaniu z innymi, jak już wcześniej wspomniano, rodzice mają możliwość wyobrażenia sobie, jak będzie wyglądała przyszłość ich dziecka. Często obserwacja innych daje rodzicom poczucie nadziei, że być może uda się przezwyciężyć obecne trudności i wyprowadzić dziecko z zaburzenia, a przynajmniej umożliwić mu samodzielne funkcjonowanie w przyszłości. To porównanie pozwala również na pogodzenie się z pewnymi faktami, na które rodzice nie mają wpływu.

Wiesz, zmieniło mi, otworzyło mi trochę oczy na takie myślenie trochę inne, że nie tak jakby my chcemy, tylko to tak, jak to dziecko chce, i w ogóle, że trzeba sobie uświadomić, że takie różne problemy, no... np., że dziecko, no może, że mogq się u niego (...). I to, i to sq inne rzeczy, no bo to... to jest też takie, że nawet jak pojechałam, bo jeżdżę na te spotkania, to tam też sq mamy chłopców, którzy robia studia i to też mnie pociesza, że to też jest droga taka, że niekoniecznie ma nie zdawać matury, że jak się postara, to zda, tylko tam te mamy maja trochę innq drogę, bo np. w wieku 12 czy 15 lat zostało to zdiagnozowane. Więc mówia, że one w ogóle dużo błędów wychowawczych robiły i wcześniej, bo nie wiedziały o tej chorobie, albo wręcz one coś podejrzewały, ale nikt ich $w$ tym nie upewnił, nie dał tej diagnozy czy nie przekonał, więc mieli trudniej, bo jakby wahali się, czy to jest ta choroba, czy nie, i ogólnie chcieli, żeby funkcjonował jako zwykłe dziecko, zdrowe. I tu pojawiały się błędy wychowawcze. My np. wiemy już, ja już wiem od 2. roku życia, czyli już 4 lata uczę się tego, jak postępować, no i może dzięki temu on lepiej funkcjonuje, 
bo teraz jak widzę jakiś problem, to reaguję na niego i uczę go, jak też on ma reagować (matka nr 5).

Natomiast w tej chwili osoby, które tam się pojawiaja, które majq̨ dzieci w wieku przedszkolnym, sq dużo lepiej wyedukowane w kwestii zespołu Aspergera, rodzajów terapii, i możliwości ośrodków niż ja. Także te 10 lat to... i to nie jest tak, że to jest jedna osoba, prawda, i ona coś tam, tylko ogólnie te możliwości w tym momencie, te możliwości terapeutyczne sq dużo lepsze. I ten przepływ informacji jest też lepszy (...). Tak, tak, jakby uzyskują dużo więcej. I... nie inaczej. Ja, cały ten mój proces to tak odbieram jak takie błądzenie po omacku... natomiast oni ida kierunkowo, oni wiedza, czego szukaja. Po prostu. I jest to, jakby zupełnie, no nie potrafię tego wytłumaczyć, ale to jest coś innego. Po prostu to jest takie bardziej efektywne, to nie jest taka strata sił, środków, czasu... (matka nr 3).

Tak. Tak, tak, tak, porównujemy. Staramy się. No bo oprócz tego każdy jakąś swoją historię opowiada, prawda? No to jeszcze czasami zdarza się, że ktoś sobie z czymś poradził, no to się dzieli tym, prawda? (matka nr 3).

\section{Także nowi ludzie, coś nowego, świeżego przynoszą, no i toczymy to, że tak powiem}

Duże znaczenie dla rodziców mają aktywności podejmowane przez grupy wsparcia i stowarzyszenia, zwłaszcza jeżeli przybierają one formę działalności lobbingowej, czyli w tym wypadku akcji mających na celu zwiększenie świadomości społecznej na temat autyzmu (np. propagujących wiedzę na temat autyzmu wśród lekarzy rodzinnych) lub zmian zmierzających do poprawy systemu wsparcia dzieci z ASD i ich rodzin. Dzięki temu rodzice mogą mieć poczucie wywierania wpływu na rzeczywistość, kontroli nad światem zewnętrznym czy „zmieniania rzeczywistości”.

Propagujemy autyzm, robiliśmy też u lekarzy pierwszego kontaktu i też widziałam nasze plakaty w poradniach, bo jedna mama jest plastykiem i ona robi te plakaty, zrobiła te plakaty: cechy autyzmu, lekarzu Stop! Tak? Że dziecko autystyczne takie ma zachowania, takie małe obrazki, historyjki były. Ja to widziałam $w$ różnych poradniach, będq̨c gdzieś tam przelotem, z dzieckiem, czy tam nie tylko. Taką akcję przez Izbę Lekarską, tam coś było takie... (matka nr 10).

Nie, w całej Polsce, w całej Polsce. Stowarzyszenie zreszta starało się trochę zmieniać rzeczywistość, to znaczy dyskutować z ministerstwem w sprawie przepisów oświatowych, w sprawie, no bolących nas wszystkich, kwestia... (matka nr 3).

Także tutaj... działamy tutaj z Urzędem Miasta, współpracujemy z innymi organizacjami, zaciszem również. Z., Sz. również, bo to Centrum Autyzmu, też w kwietniu kiedy sq te światowe dni autyzmu, to też bierzemy udział, konferencje, filmy, przecież zawsze pokaz filmów jest w kinie Mikro, w listopadzie, to bierzemy udział, razem w sumie z Centrum Autyzmu, świecimy się na niebiesko, tu jeździmy na rowerach (matka nr 10).

Organizowane z inicjatywy grup wsparcia i stowarzyszeń aktywności są również miłą formą spędzenia czasu z dziećmi, bez ryzyka, że ich dziecko zostanie wykluczone czy uznane za niewychowane, a także stają się szansą na integrację z innymi rodzicami i nawiązanie nowych przyjaźni. Pojawienie się w grupach wsparcia i stowarzyszeniach coraz to nowych członków to dla rodziców nie tylko szansa na nawiązanie nowych znajomości, ale również kopalnia pomysłów na dalszy rozwój tych grup.

Tak, zdecydowanie. Jeszcze przed tym moim okresem oni mieli wyjazd taki integracyjny organizowany, teraz $w$ tym roku się nie udało, no bo dużo czasu zajął ten ogród. To jednak trzeba brać pod uwagę to, że ludzie mając dzieci specjalnej troski, niewiele czasu im zostaje. Ale były np. wyjazdy na łowienie ryb. No i wtedy wyjazd jakby całymi rodzinami (matka $\mathrm{nr} 3$ ).

No poza tym robiliśmy kilka rzeczy, bo w tej chwili stowarzyszenie raz że uczestniczyło $w$ tych, jak były dni autyzmu, tydzień autyzmu, to mieliśmy stoisko w Galerii Bronowice, no to jak się tam stoi, prawda, 2-3 godziny z kimś, no to wiadomo, że się wymienia, każdy się wymienia tam swoją historiq (matka nr 3).

Bo tak w pierwszym momencie był taki kryzys, że tak może w pewnym momencie się to skończy. Dużo ludzi doszło nowych. I tacy państwo nawet z Gdańska czy Torunia przyjechali, on też się zajmował tymi organizacjami pożytku publicznego i dużo pomysłów ten jeden tata chorego dziecka nam też popodawał. Także nowi ludzie, coś nowego, świeżego przynosza, no i toczymy to, że tak powiem (matka nr 10).

\section{To jedna z nielicznych organizacji, która jako jedyna tak naprawdę chyba, takie coś więcej z siebie daje}

Ważne znaczenie dla rodziców może mieć także oferowane przez grupy samopomocy i zakładane przez rodziców stowarzyszenia wsparcie o charakterze instrumentalnym, np. w formie oferowania konkretnej pomocy w postaci opieki odciążającej (wytchnieniowej). Biorące udział w badaniu małżeństwo bardzo pozytywnie wypowiadało się na temat działającego na terenie województwa małopolskiego Oddziału Krajowego Towarzystwa Autyzmu oferującego bezpłatną świetlicę dla dzieci z ASD. Doceniane było to, że w trakcie zajęć świetlicowych dzieci uczyły się konkretnych umiejętności, takich jak pranie, robienie zakupów. Towarzystwo oferowało również wyjazdy wakacyjne i weekendowe dla dzieci, a także zajęcia, w których uczestniczyć mogła cała rodzina, np. wernisaże, wigilie itd.

Ale to jest z K., to nie jest, prawda, jakaś organizacja, prawda samorzq̨owa, rzq̨dowa czy lekarska, tylko to jest tak na dobra sprawę stowarzyszenie rodziców, którzy sami sobie pomagaja, i tak... I jeżeli chodzi o to, to ja uważam, że to jest jedna z nielicznych organizacji, która jako jedyna tak naprawdę chyba, takie coś więcej z siebie daje. Ci ludzie, mimo że to nie jest żaden biznes, żadnych pieniędzy na tym nie zarabiaja. A faktycznie, jest to realna pomoc, no bo ci ludzie faktycznie się zajmuja tymi dziećmi. Zarówno wtedy, kiedy ja nie bardzo mogę albo nie mam jak, robiq̨ różne terapie, chodzą gdzieś z nimi, opiekujq̨ się, uczq ich tam gotowania, sprzątania, różnych spraw, czyli taka świetlica prawdziwa. Czyli nie siedzenie przed telewizorem, prawda, i przechowalnia, tak jak w szkole, tylko coś konkretnego, no, wyjazdy wakacyjne, jakieś weekendowe, to, czego najbardziej brakuje! Odciążenie rodziców, a zarówno uczenie tych dzieci samodzielności i tego typu spraw. Bo to jest podstawa. Bo my wiecznie żyć nie będziemy, prawda? Właśnie takich organizacji brakuje (tata nr 1). 
To jest jak świetlica, oni sq od rana do dwudziestej i $w$ danych godzinach, kiedy ci tam potrzeba, żeby to dziecko było, to ci pomagają. Tam sq terapie, takie zajęcia różne, wiesz te takie... gotuja rysuja, maluja, przedstawienia, cuda. No cały czas się coś dzieje. Także to jest naprawdę niezłe dla takich dzieci, bo coś się dzieje cały czas, maja takie swoje miejsca (...). Ale też sa fajnie robione takie wiesz, wigilie, wszystko takie, wiesz, tak rodzinnie też się starają. I też patrzą ci, żeby ci jak najlepiej pomóc, a nie, że cię tak: O! traktuja (...). To nie sq takie ot, o tam. No... Także oni sa fajni (matka nr 6).

\section{DYSKUSJA}

Wiele wskazuje na to, że uczestnictwo w grupach wsparcia, samopomocy i stowarzyszeniach jest dla rodziców przede wszystkim źródłem wsparcia emocjonalnego. Dzięki przyłączeniu się do takich zrzeszeń przezwyciężali oni poczucie samotności i izolacji oraz zyskiwali poczucie przynależności do jakiejś wspólnoty - w tym wypadku do grupy rodziców przeżywających podobne co oni problemy z dzieckiem. Przede wszystkim pojawiało się poczucie znalezienia się we właściwym miejscu, trafienia do grupy wzajemnego zrozumienia, gdzie nikt nie zarzucał rodzicom, że ich dziecko jest źle wychowane. Także do miejsca, gdzie rodzice mogli przezwyciężyć poczucie odmienności, bo wreszcie nie byli tymi jedynymi, którym odbiło. Podobne wnioski zostały wyciągnięte z badań wcześniejszych, m.in. w przeglądzie systematycznym badań dokonanym przez Shilling i wsp. [6], w którym sprawdzano, jak wsparcie innych wpływa na zdrowie, samopoczucie i życie rodzinne rodziców dzieci niepełnosprawnych. Autorzy zauważyli, że uczestnictwo w grupach wsparcia pozwala rodzicom zyskać poczucie dzielonej z innymi rodzicami tożsamości społecznej. Dzięki spotkaniu innych osób w podobnej sytuacji rodzice odczuwali poczucie przynależności, wsparcia i wzmocnienia, lepiej radzili sobie w życiu codziennym, odczuwali zmniejszone poczucie izolacji, samotności i winy. Na znaczenie grup wsparcia jako miejsc bezpiecznych, gdzie rodzice mogli wyzbyć się poczucia bycia osądzanym przez innych i otwarcie mówić o uczuciach związanych z wychowywaniem dziecka niepełnosprawnego, zwrócili z kolei uwagę Law i wsp. [4] w badaniu, które stawiało sobie ze cel sprawdzenie, w jaki sposób rodzice dzieci z niepełnosprawnościami spostrzegają znaczenie wsparcia oferowanego im ze strony innych rodziców.

Uczestnictwo w grupach wsparcia, samopomocowych lub stowarzyszeniach może również ułatwiać rodzicom pogodzenie się z faktem niepełnosprawności dziecka i akceptację wynikających z tego ograniczeń. Dzięki możliwości porównania z innymi rodzice mogą łatwiej wyobrazić sobie przyszłość swojego dziecka. Spostrzeganie innych rodziców jako punkt odniesienia i źródło porównań można wytłumaczyć poprzez teorię społecznego porównania, zgodnie z którą jednostki doświadczające jakiegoś problemu (np. choroby psychicznej) szukają towarzystwa innych ludzi w podobnej sytuacji życiowej, aby odzyskać poczucie normalności [9]. Pozytywny efekt może mieć zwłaszcza porównanie społeczne w górę, ponieważ interakcja z innymi, postrzeganymi jako ci, którym udało się osiągnąć więcej niż nam, może stać się źródłem optymizmu i dawać poczucie celu, do którego można dążyć. W tym konkretnym wypadku obserwacja innych rodziców, których dzieci mimo niepełnosprawności z sukcesem rozpoczęły studia, daje rodzicom nadzieję, że być może dzięki odpowiedniej terapii i pracy uda się je w jakiś sposób wyprowadzić z niepełnosprawności.

Duże znaczenie ma również oferowane przez zrzeszenia rodziców wsparcie o charakterze informacyjnym. Spotkania grup wsparcia, samopomocowych czy stowarzyszeń rodziców dzieci z ASD stają się forum wymiany doświadczeń na temat wszystkich spraw, które w danej chwili interesują rodziców, jak również zaufanym źródłem wiedzy, do którego można się zwrócić w chwilach niepewności. Podobne wnioski wyciągnięte zostały z badania Solomona i wsp. [10], którzy stawiali sobie za cel sprawdzenie, co rodzice dzieci niepełnosprawnych i dzieci o szczególnych potrzebach (edukacyjnych) uważali za szczególnie pomocne, jeżeli chodzi o przynależność do grup samopomocowych. Zdaniem autorów jedną z ważniejszych konsekwencji posiadania dziecka niepełnosprawnego jest stan niepewności. Uczestnictwo w grupach o charakterze samopomocowym pozwalało rodzicom na zdobycie potrzebnych informacji, np. na temat tego, gdzie szukać pomocy dla dziecka. Dzięki zdobytym informacjom rodzice odzyskiwali poczucie kontroli i przewidywalności, bo wiedza stawała się ważnym narzędziem walki ze specjalistami o dobro dziecka, a w dalszej konsekwencji przezwyciężali poczucie niepewności.

Ważna dla rodziców biorących udział w badaniu była również możliwość oferowania pomocy innym. Było to dla nich istotne z psychologicznego punktu widzenia, ponieważ oni sami, w czasie największego zapotrzebowania, byli takiej formy wsparcia pozbawieni. Zwłaszcza rodzice starszych dzieci zauważali, że dzięki swoim często trudnym doświadczeniom i pozyskiwaniu na własną rękę pomocy dla dziecka wydeptywali ścieżkę innym rodzicom. Poprzez te trudne doświadczenia odczuwali wręcz misję edukowania innych, żeby komuś było łatwiej. Jak twierdzą Schilling i wsp. [6], bycie gotowym do dawania pomocy innym może być oznaką adaptacji rodzica do roli, jaką jest wychowywanie dziecka niepełnosprawnego, co oznacza, że on sam nie potrzebuje takiego wsparcia jak kiedyś. Zdaniem autorów możliwość oferowania wsparcia innym czyniła z rodziców ekspertów i zwiększała tym samym ich poczucie wartości. W wyjaśnianiu tej chęci pomagania innym szczególnie pomocna może być teoria Franka Riessmana (1965), zwana helper therapy principle, zgodnie z którą na oferowaniu pomocy innym może także zyskiwać osoba pomagająca, a wspieranie innych w podobnej sytuacji życiowej może odgrywać funkcję terapeutyczną [9].

Dzięki działalności w stowarzyszeniach rodzice mają też możliwość wywierania wpływu na zmiany w systemie wsparcia dzieci niepełnosprawnych, poprzez uczestnictwo w rożnego rodzaju akcjach o charakterze lobbingowym, lub też angażowania się w akcje, których celem jest zmiana świadomości społecznej na temat autyzmu (obchody światowego dnia autyzmu i akcje świecenia na niebiesko, festiwal filmów 
o autyzmie, akcja uświadamiająca lekarzy rodzinnych, jak rozpoznać autyzm u dziecka). Zdaniem Lawa i wsp. [4] dzięki tego typu inicjatywom i łączeniu się w większe grupy, takie jak stowarzyszenia, rodzice zyskiwali poczucie siły i uprawomocnienia. Nabywali przekonania, że tylko razem są w stanie zdziałać coś dla dobra swoich dzieci. Budowali w sobie poczucie sukcesu zarówno jako indywidualne jednostki, jak i grupa.

Ważne dla rodziców było również otrzymywane wsparcie o charakterze opiekuńczym, w postaci oferowanej im opieki odciążającej. Organizowana przez jedno z krakowskich towarzystw świetlica dla dzieci i dorosłych z ASD oraz prowadzone z inicjatywy tej samej organizacji wyjazdy weekendowe i wakacyjne dla dzieci były z punktu widzenia małżeństwa uczestniczącego w badaniu nie tylko ciekawą alternatywą spędzenia wolnego czasu dla dziecka, ale też szansą dla nich samych na chwilę odpoczynku.

W kolejnych tego typu badaniach powinno się rekrutować większą liczbę badanych, najlepiej weteranów lub nawet twórców danej organizacji wspierającej rodziców (ze szczególnym uwzględnieniem grup samopomocowych, tworzonych przez rodziców). Ważne, aby badana forma organizacji skupiającej rodziców miała bardziej jednolity charakter. Uczestniczący w niniejszym badaniu byli członkami 4 różnych form wsparcia dla rodziców: grup wsparcia prowadzonych przez profesjonalistów, grup o charakterze samopomocowym, stowarzyszeń rodziców oraz towarzystw oferujących opiekę wytchnieniową dla rodziców. Chociaż pewne doświadczania korzystających z różnych form wsparcia mają najwyraźniej charakter uniwersalny (poczucie przynależności do wspólnoty, poczucie wsparcia i większej kontroli nad światem czy doświadczanie przemiany wewnętrznej), to być może należałoby sprawdzić, jak się ma wsparcie do typu oferującej go organizacji. W celu zbadania takiej korelacji należałoby jednak przeprowadzić badanie o charakterze ilościowym.

\section{WNIOSKI}

Przeprowadzone badanie potwierdziło, że uczestnictwo w grupach skupiających rodziców dzieci z ASD, takich jak grupy wsparcia, samopomocy i stowarzyszenia, staje się dla nich przede wszystkim źródłem wsparcia emocjonalnego. Dzięki temu uczestnictwu zyskiwali oni poczucie przynależności do wspólnoty czy też grupy wzajemnego zrozumienia, przezwyciężali towarzyszące im wcześniej uczucie izolacji i osamotnienia, odzyskiwali kontrolę nad światem zewnętrznym poprzez zdobywanie informacji i instruktaży, jak załatwić terapię, opiekę lekarską czy inny rodzaj pomocy dla dziecka. W tym wymiarze uczestnictwo w grupach wsparcia, samopomocowych czy stowarzyszeniach miało także charakter poznawczo-informacyjny. Od innych rodziców, ale też od pracowników jednej z poradni psychologiczno-pedagogicznych, rodzice otrzymywali instrukcje o tym, jak radzić sobie w konkretnych sytuacjach, np. jak walczyć o realizację przez szkołę zaleceń zawartych w orzeczeniu o potrzebie kształcenia specjalnego, czyli w ten sposób korzystali również ze wsparcia o charakterze instrumentalnym. Dzięki zaangażowaniu w działalność stowarzyszeń i grup samopomocowych rodzice mieli szansę organizowania różnych form aktywności dla dzieci bez ryzyka narażenia ich na sytuacje trudne, takie jak np. wykluczenie z grupy. Nie należy również zapominać o szczególnie istotnym w przypadku rodzin dziecka z autyzmem rodzaju wsparcia, jakim jest wsparcie o charakterze opiekuńczym, polegające na zastąpieniu matki lub ojca w sprawowaniu opieki nad dzieckiem [3].

Poznanie doświadczeń rodziców dzieci z zaburzeniami ze spektrum autyzmu związanych z uczestnictwem w różnego typu zrzeszeniach skupiających rodziców, a także korzyści, jakie czerpią oni w związku z uczestnictwem w tego typu grupach, może być przydatne przy planowaniu różnego rodzaju interwencji ukierunkowanych na oferowanie regularnego wsparcia rodzicom dzieci z ASD.

\section{PIŚMIENNICTWO}

1. Pisula E. Rodzice dzieci z autyzmem. Warszawa: Wyd. Nauk. PWN; 2012.

2. Twardowski A. Sytuacja rodzin dzieci niepełnosprawnych. In: Obuchowska I, editor. Dziecko niepełnosprawne w rodzinie. Warszawa: Wyd. Szkolne i Pedagogiczne; 1991. p. 18-54.

3. Szafrańska A. Systemy i rodzaje wsparcia społecznego rodziny z dzieckiem autystycznym. Zesz Nauk Wyższej Szk Humanit Pedagog 2015;11:37-45.

4. Law M, King S, Stewart D, King G. The perceived effects of parent-led support groups for parents of children with disabilities. Phys Occup Ther Pediatr 2001;21(2-3):29-48.

5. Papageorgiou V, Kalyva E. Self-reported needs and expectations of parents of children with autism spectrum disorders who participate in support groups. Res Autism Spectr Disord 2010;4(4):653-60.

6. Shilling V, Morris C, Thompson-Coon J, Ukoumunne O, Rogers M, Logan S. Peer support for parents of children with chronic disabling conditions: a systematic review of quantitative and qualitative studies. Dev Med Child Neurol 2013;55(7):602-9. doi: 10.1111/dmcn.12091.

7. Konecki K. Metoda fenomenologicznego objaśniania doświadczanych zjawisk na podstawie autoobserwacji. Materiały wykorzystywane podczas warsztatów metodologicznych „Metoda fenomenologicznego objaśniania doświadczania zjawisk na podstawie autoobserwacji” organizowanych podczas VI Transdyscyplinarnego Sympozjum Badań Jakościowych; 2017.

8. Hycner RH. Some guidelines for the Phenomenological Analysis of interview data. Hum Stud 1985;8:279-303.

9. Solomon P. Peer support/peer provide services undelying processes, benefits and critical ingridients. Psychiatr Rehabil J 2004;27:392-401.

10. Solomon M, Pistrang N, Barker C. The benefits of mutual support groups for parents of children with disabilities. Am J Community Psychol 2001;29(1):113-32. 